\title{
Analisis Kemampuan Siswa dalam Menyelesaikan Soal Pecahan Sederhana
}

\author{
Luh Ermayani ${ }^{1}$, I Made Suarjana ${ }^{2}$, Desak Putu Parmiti ${ }^{3}$ \\ 1,2 Jurusan Pendidikan Guru Sekolah Dasar, ${ }^{3}$ Jurusan TP FIP \\ Universitas Pendidikan Ganesha \\ Singaraja, Indonesia \\ e-mail : ermayani469@yahoo.co.id ${ }^{1}$, suarjana_undiksha@yahoo.co.id ${ }^{2}$, \\ dskpt parmiti@yahoo.com ${ }^{3}$
}

\begin{abstract}
Abstrak
Penelitian ini bertujuan untuk mendeskripsikan: (1) proses pembelajaran pecahan sederhana di kelas III SD, (2) Kemampuan siswa menyelesaikan soal pecahan sederhana, (3) Kesulitan yang dihadapi siswa dalam menyelesaikan soal pecahan sederhana dan solusi untuk mengatasi kesulitan dalam menyelesaikan soal pecahan sederhana. Jenis penelitian ini adalah deskriptif kuantitatif dan kualitatif. Populasi penelitian ini adalah siswa kelas III SD Gugus VII kecamatan Sukasada yang berjumlah 134 orang dan guru kelas III. Sampel penelitian ini ditentukan dengan teknik proposional sampel dapat dilihat pada tabel Isaac and Michel. Sehingga jumlah sampel dalam penelitian ini adalah 95 orang siswa. Objek penelitian ini adalah (1) proses pembelajaran pecahan sederhana kelas III SD, (2) kemampuan siswa dalam menyelesaikan soal pecahan sederhana, (3) kesulitan yang dihadapi siswa dalam menyelesaikan soal pecahan sederhana dan solusi mengatasi kesulitan tersebut. Metode pengumpulan data yang digunakan adalah observasi, tes,wawancara dan dokumentasi. Teknik analisis data menggunakan analisis deskriptif kuantitatif dan kualitatif. Hasil penelitian menunjukkan (1) rata-rata hasil tes secara klasikal 64,07 dengan kategori rendah. (2) Kesulitan yang dihadapi siswa dalam menyelesaikan soal pecahan sederhana yaitu membandingkan pecahan sederhana, memahami soal cerita. Solusi untuk mengatasi hal tersebut adalah sering memberikan latihan soal, menggunakan bahasa Indonesia dalam pembelajaran, memberikan banyak variasi soal dan perlu adanya inovasi dalam proses pembelajaran. (3) Faktor penyebab kesulitan dalam menyelesaikan soal pecahan sederhana berdasarkan hasil wawancara dengan guru wali kelas III secara umum meliputi minat dan motivasi, faktor guru, faktor lingkungan.
\end{abstract}

Kata Kunci: kemampuan,matematika,pecahan sederhana.

\begin{abstract}
This aims of this study is to describe: (1) learning process of simple fractionin grade Illelementary school, (2) the ability of studentinsolvingsimple fraction problem, (3) difficulties faced by student in solving simple fraction problem and solution to overcome the difficulties. This study is descriptive quantitative and qualitative kind of research. The population of this study is the elementary students grade IIlof Gugus VII Sukasada sub-district which is 134 students and the teacher of grade III class. The sample of this research is determined by the sample proportional technique and can be seen on Isaac and Michel table. So, the number of samples in this study are 95 students. The object of this research are (1) learning process of simple fraction in elementary school grade III, (2) the ability of student in solving simple fraction problem, (3) the difficulties faced by student in solving simple fraction problem and solution to overcome the difficulties. Observation, test, interview and documentation method were used in collecting the data. Quantitative and qualitative descriptive analysis were used in analyzing the collected data. The results shows that (1) the process of learning a simple fraction is in a good category. (2) the average test result is classically 64,07 with low category. (3) The difficulties faced by students in solving simple fractional problems is to compare the simple fraction itself andto understand the problem in the form of story. The solutions to overcome this situation is frequently practicing the questions, usinglndonesian language as a mean in learning process, providing many variations of the problem andinnovating in the learning process.
\end{abstract}

Keywords: ability, math, simple fractions. 


\section{Pendahuluan}

Pada jenjang pendidikan Sekolah Dasar (SD) memberikan berbagai keterampilan dasar yang akan menjadi pondasi awal pengetahuan siswa. Pada pembelajaran di SD terdapat lima mata pelajaran pokok yang tercantum dalam kurikulum di Indonesia dan selalu diberikan pada setiap jenjang pendidikan, salah satunya yaitu mata pelajaran matematika. Menurut Septiani, (2016) "Pendidikan matematika pada jenjang pendidikan SD memiliki peran penting dalam proses pendidikan siswa". Pentingnya penguasaan matematika terlihat pada Undang-Undang RI No. 20 Tahun 2003 Tentang Sisdiknas Pasal 37 ditegaskan bahwa mata pelajaran matematika merupakan salah satu mata pelajaran wajib bagi siswa pada jenjang pendidikan dasar dan menengah.

Menurut Susanto (2013), "Matematika merupakan disiplin ilmu yang dapat meningkatkan kemampuan berpikir dan berargumentasi serta memberikan kontribusi dalam pemecahan masalah yang dihadapi dalam kehidupan sehari-hari". Pernyataan di atas sejalan dengan pendapat Japa \& Suarjana (2014:3) menyatakanperlu disadari bahwa "dibelajarkannya Matematika kepada semua peserta didik mulai dari tingkat sekolah dasar adalah untuk membekali mereka berbagai kemampuan seperti: kemampuan berpikir logis, analitis, sistematis kritis dan kreatif, serta kemampuan untuk bekerjasama".

Prihandoko (dalam Andika, 2017) menyatakan penguasaan terhadap matematika sangat diperlukan dan pemahaman terhadap konsep-konsep Matematika perlu diperhatikan dengan benar. Alasannya, konsep-konsep Matematika merupakan rangkaian sebab akibat. Suatu konsep disusun berdasarkan konsep-konsep sebelumnya dan akan menjadi konsepkonsep selanjutnya, sehingga pemahaman konsep yang salah akan berakibat pada kesalahan pada konsep selanjutnya. Dengan demikian, matematika adalah ilmu yang sangat penting dipelajari yang menjadi dasar untuk mempelajari ilmu lain, sehingga pemahaman konsep matematika siswa harus dikuasai secara benar. Namun kenyataan yang terjadi, pemahaman konsep matematika belum dikuasai oleh siswa. Pemahaman konsep merupakan pengetahuan awal yang dimiliki seseorang yang dapat digunakan untuk memecahkan suatu permasalahan, yang berkaitan dengan pengetahuan yang telah ia miliki.

Sebagai bukti bahwa pemahaman konsep matematika siswa masih kurang yaitu, hasil tes yang dilakukan oleh Program for Internasional Student Assement (PISA) pada tahun 2012 (dalam Andika, 2017) dinyatakan bahwa penguasaan matematika siswa Indonesia berada pada peringkat 63 dari 64 negara. Pada tahun 2015 Indonesia berada pada peringkat 62 dari 70 negara. Selanjutnya, hasil tes yang dilakukan oleh Trend in Internasional Mathematics and Scienes Study (TIMSS) pada tahun 2015 Indonesia berada pada peringkat 44 dari 49 negara. Hal ini membuktikan bahwa pemahaman konsep matematika siswa Indonesia masih sangat kurang.

Sebagaimana telah disinggung pada bagian awal, bahwa penyelenggaraan pendidikan pada jenjang SD bertujuan memberikan bekal kepada siswa untuk hidup bermasyarakat dan dapat melanjutkan pendidikan ke jenjang yang lebih tinggi, maka tujuan pembelajaran matematika di sekolah dimaksudkan agar siswa tidak hanya terampil menggunakan matematika, tetapi dapat memberikan bekal kepada siswa dengan tekanan penataan nalar dalam penerapan matematika dalam kehidupan sehari-hari di tengah-tengah masyarakat di mana ia tinggal.

Pada usia siswa SD (7-8 tahun hingga 12-13 tahun), menurut teori kognitif Piaget termasuk pada tahap operasional konkret. Berdasarkan perkembangan kognitif ini maka anak usia SD pada umumnya mengalami kesulitan dalam memahami matematika yang bersifat abstrak, karena keabstrakannya matematika relatif tidak mudah untuk dipahami oleh siswa SD pada umumnya.

Bidang studi matematika merupakan salah satu komponen pendidikan dasar dalam bidang pengajaran. Bidang studi matematika ini diperlukan untuk proses perhitungan dan proses berpikir yang sangat dibutuhkan orang dalam menyelesaikan berbagai masalah. Banyak materi pelajaran yang diajarkan pada mata pelajaran matematika di tingkat SD. Salah satunya yaitu materi pecahan. Materi pecahan sederhana merupakan konsep awal siswa SD mengenal pecahan.

Dengan menguasai konsep-konsep matematika sejak dini, diharapkan siswa mendapat bekal yang cukup untuk menghadapi materi matematika pada tingkat pendidikan lanjutan serta dapat menggunakannya dalam kehidupan sehari-hari. Pecahan merupakan salah satu topik yang sulit untuk diajarkan. Oleh karena itu, matematika sebaiknya diajarkan melalui berbagai masalah yang ada di sekitar siswa dengan memperhatikan usia dan pengalaman yang dimiliki 
siswa agar siswa dapat mencapai hasil belajar yang baik dan dapat mengembangkan aktivitasnya dalam pembelajaran maka proses pembelajaran harus dikemas sedemikian rupa dengan memanfaatkan segala potensi yang dimiliki oleh siswa. Siswa perlu dilibatkan secara aktif dalam proses pembelajaran. Dengan demikian diperlukan adanya suatu strategi yang tepat dalam pembelajaran sehingga tujuan pembelajaran yang diharapkan dapat tercapai.

Namun demikian, pelajaran matematika bagi sebagian besar siswa masih dianggap pelajaran yang sulit dan menakutkan. Ketakutan terhadap mata pelajaran matematika lebih disebabkan kurangnya peran guru dalam menggunakan strategi, model-model pembelajaran dalam mengembangkan konsep dasar pelajaran berhitung. Ditambah lagi pembelajaran matematika di sekolah jarang sekali melibatkan alat peraga. Konsep matematika yang abstrak menjadi sulit untuk dibayangkan oleh siswa. Menurut Rudhiyama (2016: 2) pembelajaran Matematika dalam KTSP bercirikan,(1) menggunakan permasalahan yang kontekstual, yaitu permasalahan yang nyata dan dapat dibayangkan oleh siswa, (2) mengembangkan kemampuan memecahkan masalah (problem solving) dan berkomunikasi matematis, (3) memberikan kesempatan yang luas untuk penemuan kembali (reinvention) dan untuk membangun (construction) konsep, definisi, prosedur dan rumus-rumus matematika secara mandiri, (4) melatih cara bernalar dalam menarik kesimpulan (5) mengembangkan kreativitas yang melibatkan imajinasi, intuisi, dan penemuan melalui pemikiran divergen dan coba-coba (trial and eror), (6) menggunakan model (modeling), dan (7) memperhatikan dan mengakomodasikan perbedaan-perbedaan karakter individual siswa.

Hasil observasi yang dilakukan dengan cara pengambilan dokumentasi dan wawancara ditemukan permasalahan yaitu rendahnya hasil belajar matematika siswa. Selanjutnya dilakukan pengambilan data dokumentasi berkaitan dengan hasil belajar materi pecahan sederhana rendah dan hasil wawancara yang dilakukan dengan guru kelas III gugus VII Kecamatan Sukasada materi pelajaran yang dirasakan sulit untuk dipahami siswa adalah materi pecahan. Pada pembelajaran pecahan siswa merasa sulit mengerjakan soal-soal operasi hitung pecahan sederhana. Selain itu pemilihan dan penggunaan media/alat peraga untuk mengajarkan materi pecahan dirasa cukup sulit sehingga proses pembelajaran di kelas III hanya menggunakan panduan sesuai dengan apa yang ada di buku paket dan jarang menggunakan alat peraga pada proses pembelajaran.

Berdasarkan uraian yang telah dipaparkan, maka perlu dilakukan analisis kemampuan siswa dalam menyelesaikan soal matematika khususnya materi pecahan sederhana yang nantinya diharapkan mampu memberikan informasi sejauh mana pemahaman siswa terhadap materi, apa kesulitan yang dihadapi, maka dari masalah tersebut dapat dicarikan solusi sehingga pembelajaran diharapkan mampu meningkatkan hasil belajar matematika siswa. Dari pemaparan masalah di atas maka perlu dilakukannya "Analisis Kemampuan Siswa Dalam Menyelesaikan Soal Pecahan Sederhana Kelas III SD Gugus VII Kecamatan Sukasada Tahun Pelajaran 2017/2018".

Hakikat matematika adalah salah satu disiplin ilmu yang mempelajari tentang logika, mengenai kemampuan berpikir logis, analitis, sistematis, kritis dan kreatif dapat meningkatkan kemampuan berpikir dan berargumentasi, memberikan kontribusi dalam penyelesaikan masalah sehari-hari dan dalam dunia kerja serta memberikan dukungan dalam pengembangan ilmu pengetahuan dan teknologi.Pembelajaran matematika di SD merupakan suatu proses belajar mengajar yang mengandung dua jenis kegiatan yang tidak terpisahkan, baik guru maupun siswa bersama-sama menjadi pelaku terlaksnanya tujuan pembelajaran dengan melibatkan seluruh siswa secara aktif. Sehingga siswa mampu menunjukkan semangat belajar yang tinggi, percaya diri dan terjadi perubahan tingkah laku ke arah positif sehingga tercapainya tujuan pembelajaran yang sudah ditetapkan.

Kemampuan yang dimiliki siswa dalam pelajaran matematika berbeda antara siswa satu dengan siswa lain, Susanto (2013) mempunyai pendapat bahwa "kemampuan merupakan potensi dasar bagi pencapaian hasil belajar yang dibawa sejak lahir. Sejalan dengan pendapat Susanto, kemampuan dapat diartikan sebagai kesanggupan, kecakapan, kekuatan atau potensi bawaan sejak lahir yang dapat digunakan untuk melakukan suatu perbuatan". Salah satu penyebab rendahnya kemampuan siswa yaitu adanya kesulitan belajar.

Indikator kesulitan belajar diantaranya(Lestari \& Yudhanegara, 2017) (1) Ketidakmampuan untuk mengingat nama-nama secara teknis, (2) ketidakmampuan untuk menyatakan arti dari istilah yang mewakili konsep tertentu, (3) ketidakmampuan untuk mengingat satu kondisi atau lebih yang diperlukan, (4) ketidakmampuan mengingat syarat cukup untuk memberikan istilah bagi suatu objek tertentu, (5) ketidakmampuan memberikan 
contoh dan bukan contoh dari suatu konsep tertentu, (6) ketidakmampuan menyimpulkan informasi dari suatu konsep yang diberikan.

\section{Metode}

Populasi dapat didefinisikan "sebagai sejumlah kasus yang memenuhi seperangkat kriteria tertentu yang ditentukan peneliti" (Dantes, 2012:37). Populasi yang digunakan dalam penelitian ini adalah siswa kelas III Gugus VII Kecamatan Sukasada Kabupaten Buleleng yang terdiri dari 6 SD sejumlah 134 orang siswa . Menurut Agung (2014:69) sampel ialah "sebagian dari populasi yang diambil, yang dianggap mewakili seluruh populasi dan diambil dengan menggunakan teknik tertentu". Dalam penelitian ini menggunakan teknik proporsional sampel. Penentuan sampel dapat dilihat pada tabel Isaac and Michel. Dalam tabel tersebut dijelaskan tentang besarnya sampel yang diambil dari populasi dengan tingkat kesahalan $1 \%, 5 \%$, dan $10 \%$. Sampel dalam penelitian ini sebanyak 95 orang siswa.

Metode yang digunakan dalam penelitian ini yaitu(1) metode observasi adalah teknik pengumpulan data dengan cara mengamati secara langsung maupun tidak tentang hal-hal yang diamati dan mencatatnya pada alat observasi, pada tahap observasi, peneliti hadir di kelas dan melakukan observasi untuk mengetahui bagaimana proses pembelajaran pecahan sederhana di kelas III SD gugus VII Kecamatan sukasada. (2) Metode tes adalah instrument atau alat untuk mengumpulkan data tentang kemapuan subjek penelitian dengan cara pengukuran, misalnya untuk mengukur kemampuan subjek penelitian dalam menguasai materi pelajaran tertentu, digunakan tes tertulis tentang materi pelajaran tersebut, untuk mengukur kemampuan subjek penelitian dalam menggunakan alat tertentu (Sanjaya,2013:251).(3) Wawancara dilakukan terhadap guru dan siswa untuk memperoleh data berkaitan dengan kesulitan-kesulitan yang dihadapi siswa dalam menyelesaikan soal pecahan sederhana dan solusi untuk mengatasi kesulitan tersebut. (4) Metode Dokumentasi Cara pengumpulan data melalui peninggalan tertulis seperti arsip-arsip dan termasuk juga buku-buku tentang pendapat, teori, dalil atau hukum-hukum, dan lain-lain yang berhubungan dengan masalah penelitian disebut teknik dokumenter. Dokumentasi dilakukan dengan mencatat dan mengabadikan kegiatan berupa foto-foto pada saat peneliti melakukan observasi kegiatan pembelajaran di kelas. Dokumentasi dirancang untuk mengumpulkan data-data mengenai bagaimana proses pembelajaran pecahan sederhana di kelas III di gugus VII Kecamatan Sukasada Kabupaten Buleleng Tahun pelajaran 2017/2018. Berkaitan dengan paparan tersebut, instrumen penelitian ini adalah (1) lembar observasi, (2) pedoman wawancara, (3) tes dan (4) pedoman dokumentasi.

Metode analisis data dalam penelitian ini, jenis data yang diteliti adalah data kualitatif dan kuantitatif berupa deskripsi siswa dalam menyelesaikan soal-soal pecahan sederhana. Analisis data deskriptif kualitatif dan kuantitatif diarahkan pada identifikasi dan klarifikasi untuk mendapat deskripsi yang jelas, rinci, dan memadai berkenaan dengan analisis kemampuan siswa dalam menyelesaiakan soal pecahan sederhana pada siswa kelas III di Gugus VII Kecamatan Sukasada Kabupaten Buleleng Tahun Pelajaran 2017/2018. Untuk teknik analisis data, rumusan masalah pertama digunakan teknik analisis deskriptif kuantitatif kedua digunakan teknik analisis deskriptif kuantitatif dan kualitatif serta untuk rumusan masalah ketiga digunakan teknik analisis deskriptif kuantitatif. Dapat dilihat pada Tabel 1 sebagai berikut.

Tabel 1. Teknik Analisis

\begin{tabular}{llllll}
\hline No & \multicolumn{1}{c}{ Variabel } & $\begin{array}{l}\text { Metode } \\
\text { Pengumpulan } \\
\text { Data }\end{array}$ & Sumber & Sifat Data & $\begin{array}{l}\text { Metode Analisis } \\
\text { Data }\end{array}$ \\
\hline 1 & $\begin{array}{l}\text { Kemampuan siswa } \\
\text { menyelesaikan soal } \\
\text { pecahan sederhana }\end{array}$ & Tes Essay & Siswa & Nilai & $\begin{array}{l}\text { Deskriptif } \\
\text { Kuantitatif }\end{array}$ \\
$2 \begin{array}{l}\text { Kendala-kendala dan } \\
\text { solusi yang dihadapi } \\
\text { dalam menyelesaikan soa } \\
\text { pecahan sederhana }\end{array}$ & $\begin{array}{l}\text { Catatan } \\
\text { Dokumen }\end{array}$ & $\begin{array}{l}\text { Guru dan } \\
\text { Wawancara }\end{array}$ & Siswa & Deskripsi & $\begin{array}{l}\text { Deskripsi } \\
\text { Kualitatif }\end{array}$ \\
\hline
\end{tabular}




\begin{tabular}{|c|c|c|c|}
\hline $\begin{array}{ll}3 & \text { Faktor Penyebab } \\
& \text { Kesulitan dalam } \\
& \text { Menyelesaikan Soal }\end{array}$ & $\begin{array}{c}\text { Observasi } \\
\text { dan Wawancara }\end{array}$ & Guru dan & Deskripsi \\
\hline
\end{tabular}

\section{Hasil dan Pembahasan}

Hasil penelitian ini mendeskripsikan hasil observasi yang dilaksanakan pada bulan Maret sampai bulan April 2018 di kelas III gugus VII Kecamatan Sukasada, hasil tes menyelesaikan soal pecahan sederhana yang telah diberikan kepada siswa dan hasil wawancara dengan guru kelas dan siswa serta hasil dokumentasi. Tes dilakukan untuk menjawab rumusan masalah yang kedua yaitu kemampuan siswa dalam menyelesaikan soal pecahan sederhana. Wawancara dilakukan untuk mengetahui kesulitan-kesulitan yang dihadapi siswa dalam menyelesaikan soal pecahan sederhana dan solusi untuk mengatasi kesulitan-kesulitan tersebut. Observasi dan dokumentasi dilakukan untuk menjawab rumusan masalah ketiga yaitu Faktor penyebab kesulitan dalam menyelesaikan pecahan sederhana di kelas III.

Kemampuan siswa dalam menyelesaikan soal pecahan sederhana di gugus VII Kecamatan Sukasada diukur berdasarkan tes essay dengan 5 indikator yang terdiri dari 10 soal. Hasil tes kemampuan siswa menyelesaikan soal pecahan sederhana di kelas III gugus VII Kecamatan Sukasada secara individu diperoleh nilai tertinggi 90 dan nilai terendah yang diperoleh adalah 30 . Untuk rata-rata hasil tes siswa dalam menyelesaikan soal pecahan sederhana secara klasikal diperoleh nilai 64,07 yang termasuk kategori baik, tetapi jika dikaitkan berdasarkan KKM kemampuan siswa dalam menyelesaikan soal pecahan masih di bawah KKM. Berikut ini disajikan hasil tes kemampuan siswa dalam menyelesaikan soal pecahan sederhana kelas III gugus VII kecamatan Sukasada sebagai berikut

Tabel 2. Hasil Kemampuan Siswa dalam Menyelesaikan Soal Pecahan Sederhana

\begin{tabular}{cccc}
\hline $\begin{array}{c}\text { No } \\
\text { Soal }\end{array}$ & $\begin{array}{c}\text { Jumlah Siswa Menjawab Benar } \\
\text { dari 95 orang siswa }\end{array}$ & Persentase & Kategori \\
\hline $\mathbf{1}$ & 69 orang siswa & $72.63 \%$ & Sedang \\
$\mathbf{2}$ & 55 orang siswa & $57.89 \%$ & Rendah \\
$\mathbf{3}$ & 52 orang siswa & $54.73 \%$ & Rendah \\
$\mathbf{4}$ & 51 orang siswa & $53.68 \%$ & Rendah \\
$\mathbf{5}$ & 29 orang siswa & $30.52 \%$ & Sangat Rendah \\
$\mathbf{6}$ & 21 orang siswa & $22.10 \%$ & Sangat Rendah \\
$\mathbf{7}$ & 43 orang siswa & $45.26 \%$ & Rendah \\
$\mathbf{8}$ & 38 orang siswa & $40 \%$ & Rendah \\
$\mathbf{9}$ & 21 orang siswa & $22.10 \%$ & Sangat Rendah \\
$\mathbf{1 0}$ & 16 orang siswa & $16.84 \%$ & Sangat Rendah \\
\hline
\end{tabular}

Hasil analisis kemampuan siswa dalam menyelesaikan soal pecahan sederhana siswa kelas III SD gugus VII Kecamatan Sukasada menunjukkan rata-rata kemampuan siswa masih rendah. Berdasarkan hasil analisis kemampuan siswa dalam menyelesaika soal nomor 1 sampai dengan soal nomor 10 menunjukkan kemampuan siswa dalam menyelesaikan soal nomor 1 termasuk kategori sedang, kemampuan siswa dalam menyelesaikan soal nomor 2, 3, 4, 7, 8 termasuk dalam kategori rendah, dan soal nomor 5, 9, 10 kemampuan siswa dalam menyelesaikan soal pecahan sederhana termasuk dalam kategori sangat rendah. Penyebab kemampuan siswa dalam menyelesaikan soal nomor 5,9,10 termasuk dalam kategori rendah yaitu siswa masih sulit memahami soal cerita pecahan sederhana padahal siswa sudah sering dilatih dengan soal demikian pada saat pembelajaran.

Berdasarkan pengolahan skor yang dilakukan diperoleh hasil tes siswa yang beragam antara siswa yang satu dengan siswa yang lain. Nilai tertinggi yang diperoleh siswa yaitu 90 dan nilai terendah adalah 30. Dari hasil pengolahan skor, 2 orang siswa memperoleh nilai dengan kategori sangat tinggi, 19 orang siswa memperoleh nilai dengan kategori tinggi, 28 orang siswa memperoleh nilai dengan kategori sedang, 39 orang siswa memperoleh nilai dengan kategori rendah dan 7 orang siswa memperoleh nilai dengan kategori sangat rendah, dan secara 
klasikal diperoleh nilai rata-rata siswa yaitu 64,07 Untuk mengetahui tingkat kemampuan siswa dalam menyelesaikan soal pecahan sederhana digunakan pedoman yang sesuai dengan tabel Konversi Penilaian Acuan (PAP) skala lima tentang kemampuan siswa dalam menyelesaikan soal pecahan sederhana berada pada kategori baik. Namun, jika dikaitkan dengan nilai KKM siswa di Gugus VII Kecamatan Sukasada, nilai rata-rata 64,07 masih dibawah KKM sehingga, kemampuan siswa dalam menyelesaikan soal pecahan sederhana masih perlu ditingkatkan. Dalam menyelesaikan soal pecahan sederhana siswa masih mengalami kesulitan baik dalam menentukan nilai pecahan, membandingkan 2 pecahan, serta menyelesaikan soal cerita. Hasil analisis tersebut, sejalan dengan penelitian yang dilakukan oleh Suaryani (2016) yang mengungkapkan bahwa kemampuan siswa dalam menyelesaikan operasi hitung khususnya pada materi pecahan masih perlu ditingkatkan karena tergolong kategori rendah.

Berdasarkan analisis yang telah dilakukan dan diperkuat oleh pendapat di atas menunjukkan bahwa kemampuan siswa dalam menyelesaikan soal pecahan sederhana perlu ditingkatkan lagi, guna tercapainya tujuan pembelajaran di dalam sebuah proses pembelajaran.

Hasil wawancara dengan guru kelas III, diperoleh informasi bahwa kesulitan yang dihadpi siswa menyelesaikan soal pecahan sederhana yaitu dalam memahami soal karena ada beberapa siswa belum lancar dalam membaca, kesulitan dalam memahami masalah berupa soal cerita. Menurut guru kelas III, untuk mengatasi hal tersebut perlu banyak latihan soal berkaitan dengan pecahan sederhana, dan juga peran orang tua untuk membantu anak untuk belajar dirumah karena waktu anak di sekolah belajar hanya sedikit jadi peran orang tua juga sangat dibutuhkan untuk dapat meningktakan kemampuan siswa.

Berdasarkan hasil penelitian, temuan ini juga sejalan dengan hasil penelitian Widyasari (2015) menunjukkan bahwa siswa mengalami kesulitan belajar yang ditunjukkan dengan kesalahankesalahan siswa dalam menjawab soal yang diberikan. Selain itu, hasil penelitian Suaryani (2016) siswa mengalami kendala saat menyelesaikan soal cerita penggunaan bahasa Indonesia dalam pembelajaran jarang digunakan sehingga siswa sulit menyelesaikan soal cerita.

Dari hasil wawancara yang dilakukan dengan guru dan beberapa siswa, dapat ditarik kesimpulan bahwa siswa kurang paham dengan pecahan sederhana jika diminta untuk membandingkan pecahan dan juga soal yang berbentuk soal cerita sehingga sering keliru mejawab soal.

Solusi untuk mengatasi kesulitan yang dihadapi siswa dalam menyelesaikan soal pecahan sederhana yaitu dengan memberikan beberapa contoh soal pada saat proses pembelajaran berlangsung dan lebih sering memberikan latihan soal yang beragam kepada siswa. Memberikan pekerjaan rumah agar siswa dapat latihan soal di rumah.

Adapun solusi lain yang ditawarkan peneliti yaitu hendaknya dalam proses pembelajaran khususnya dalam mengajarkan materi pecahan sederhana guru lebih memvariasikan pembelajaran dengan menggunakan media pembelajaran, alat peraga yang dapat membantu siswa lebih mudah memahami sesuatu, sejalan dengan pendapat (Untari, dkk 2017:93) menyatakan bahwa" penggunaan media pembelajaran dalam proses pembelajaran akan membantu kelancaran, efektivitas dan efisiensi pencapaian tujuan pembelajaran". Menerapkan metode atau model pembelajaran. Selain itu dalam proses pembelajaran perlu melibatkan siswa secara aktif. Metode yang dapat digunakan pada pembelajaran inovatif, misalnya metode diskusi yang melibatkan peserta didik untuk membicarakan dan menemukan alternative pemecahan suatu topik bahasan yang bersifat problematis, sehingga hal tersebut menyebabkan pembelajaran akan lebih hidup dan bermakna sehingga nantinya dapat meningkatkan hasil belajar menjadi lebih baik.

Pembahasan pada penelitian ini mendeskripsikan mengenai faktor-faktor penyebab kesulitan siswa dalam menyelesaikan soal pecahan sederhana siswa kelas III SD gugus VII kecamatan Sukasada. Untuk memperoleh informasi mengenai faktor-faktor kesulitan tersbut, dilakukan wawancara dan observasi proses pembelajaran pecahan sederhana.

Dalam menyelesaikan soal pecahan sederhana siswa kelas III SD Gugus VII Kecamatan Sukasada mengalami kesulitan. Kesulitan tersebut dikarenakan adanya hambatanhambatan atau adanya faktor-faktor yang mempengaruhi dalam mencapai suatu hasil belajar sehingga kesulitan menyebabkan ketidakmampuan siswa kelas III menyelesaikan soal pecahan sederhana. Hal tersebut sejalan dengan pendapat dari Mulyadi (2010:6) menyatakan bahwa "Kesulitan merupakan suatu kondisi tertentu yang ditandai dengan adanya hambatan-hambatan dalam kegiatan mencapai tujuan, sehingga memerlukan usaha lebih giat lagi untuk dapat mengatasinya". 
Terkait dengan faktor-faktor penyebab kesulitan menyelesaikan pecahan sederhana yang dihadapi siswa, berdasarkan hasil wawancara faktor-faktor tersebut terdiri dari dua faktor, yaitu faktor internal dan eksternal.

Pada faktor internal dibagi menjadi tiga aspek yaitu faktor pengetahuan awal siswa, faktor pemahaman konsep siswa, dan faktor minat dan motivasi siswa.

1. Faktor pengetahuan awal siswa

Kesulitan siswa dalam menyelesaikan operasi hitung pecahan dapat disebabkan karena kurangnya pengetahuan awal siswa. Pengetauan awal digunakan sebagai bentuk dasar konsep serta kerangka dalam berpikir yang dimiliki siswa dipergunakan dalam mengorganisasikan dan menafsirkan informasi yang diperoleh siswa. Kurangnya pengetahuan awal siswa ditandai dengan siswa mengalami kesulitan saat menyelesaikan soal operasi hitung pecahan, yaitu siswa tidak bisa melakukan penjumlahan atau pengurangan pecahan berpenyebut tidak sama, siswa tidak bisa menyederhanakan pecahan.

2. Faktor Pemahaman Konsep Siswa

Pemahaman konsep siswa yang masih salah merupkan salah satu penyebab kesulitan siswa dalam menyelesikan soal pecahan sederhana. Karena pemahaman konsep siswa masih salah mengakibatkan siswa sering melakukan kesalahan saat menggunakan konsep pecahan sederhana yaitu dalam menentukan nilai pecahan sederhana, membandingkan pecahan sederhana operasi hitung penjumlahan dan pengurangan. Siswa masih merasa bingung saat menyelesaikan soal cerita saat tahap penyelesaian operasi penjumlahan siswa ikut menjumlahkan penyebut dari nilai pecahan tersebut.

3. Faktor Minat dan Motivasi Siwa

Minat berkaitan dengan ketertarikan siswa untuk mempelajari matematika khususnya materi pecahan sederhana serta sikap siswa terhadap pembelajaran operasi hitung pecahan. Motivasi berkaitan dengan perhatian siswa terhadap pembelajaran pecahan sederhana serta usaha siswa untuk terlibat di dalam proses belajar.

Berdasarkan hasil wawancara minat dan motivasi siswa masih kurang dalam pembelajaran matematika khususnya materi pecahan sederhana karena siswa menganggap matematika sebagai pelajaran yang sulit dan menakutkan. Hal tersebut terbukti dengan hasil tes pecahan sederhana yang dikerjakan, siswa banyak yang salah tidak mengikuti tahap bagaimana cara menjawab dengan benar. Saat mengikuti proses pembelajaran kurang aktif menjawab soal maupun bertanya jika belum paham dengan materi yang diajarkan oleh guru.

Faktor yang mempengaruhi juga berasal dari faktor eksternal, yaitu faktor guru, saranaprasarana dan lingkungan.

1. Faktor Guru

Faktor guru juga menyebabkan siswa kesulitan dalam menyelesaikan pecahan sederhana. Karena dalam menjelaskan materi guru hanya terbatas dengan menjelaskan pada papan tulis serta cara penyampaian materi dianggap masih terlalu cepat, kurangnya latihan-latihan soal yang diberikan guru memicu rendahnya hasil belajar siswa. Serta tidak adanya penggunaan media atau alat peraga. Abdurahman (2012) menyatakan faktor guru yang berasal dari strategi pembelajaran yang keliru seperti pengelolaan aktivitas belajar yang tidak membangkitkan motivasi belajar anak, metode yang digunakan oleh guru kurang bervariasi sehingga pembelajaran menjadi membosankan, serta kurangnya penggunaan media pembelajaran atau alat peraga di dalam proses belajar mengajar.

2. Faktor Sarana prasarana

Sarana prasarana yang masih belum memadai juga menjadi penyebab kesulitan siswa dalam menyelesaikan pecahan sederhana karena kurang mendukung suasana dan kegiatan pembelajaran yang berlangsung

3. Faktor Lingkungan

Lingkungan juga berpegaruh menjadi penyebab kesulitan siswa dalam menyelesaikan soal pecahan sederhana. Kurangnya peran orangtua atau keluarga dalam mengawasi dan mendidik anak belajar di rumah mengakibatkan anak menjadi kesulitan dalam pembelajaran.

4. Kegiatan Proses Pembelajaran

Pada saat observasi proses pembelajaran di Gugus VII Kecamatan Sukasada kelas III SD guru mengawali pembelajaran dengan mengucapkan salam dan mengajak siswa untuk berdoa sebelum mulai pelajaran serta mengecek kehadiran siswa, setelah itu guru menjelaskan materi yang akan dibahas mengenai materi pecahan sederhana. 
Pada saat proses pembelajaran pecahan sederhana guru menggunakan alat peraga agar siswa mudah memahami materi seperti gambar, kertas yang dilipat kemudian siswa diminta menyebutkan nilai dari suatu pecahan tersebut. Mengaitkan materi pecahan dengan kehidupan sehari-hari agar siswa mampu dipahami oleh siswa. Pentingnya mengaitkan meteri dengan kehidupan nyata siswa juga disampaikan oleh (Budiasih 2017) bahwa " pembelajaran khususnya bagi anak SD yang masih berada pada tahap operasional konkret, untuk mengajarkan matematika hal yang harus dilakukan adalah dengan mengaitkan materi ajar dengan dunia nyata yang dekat dengan anak dalam kehidupan sehari-hari".

Kemudian siswa diajak untuk tanya jawab untuk mengetahui seberapa paham siswa, guru memberikan contoh soal yang dituliskan dipapan tulis kemudian menunjuk siswa untuk menuliskan jawaban dipapan tulis. Setelah siswa sudah paham dengan penjelasan guru kemudian guru kembali memberikan latihan soal kepada siswa yang dibuat dibuku latihan siswa, guru membimbing siswa saat menjawab soal. Setelah semua siswa selesai menjawab guru membahas pekerjaan siswa dengan menunjuk siswa untuk menulis di papan tulis. Diakhir pembelajaran guru memberikan tugas rumah (PR) berkaitan dengan apa yang sudah dipelajari. Pada saat menutup pelajaran guru kembali mengajak siswa berdoa dan mengucapkan salam.

Berdasarkan hasil observasi dalam proses pembelajaran yang telah dilaksanakan guru dengan materi pecahan sederhana dapat disimpulakan bahwa cara mengajar guru termasuk dalam kategori baik yaitu dengan nilai rata-rata 81,83 . Dengan menggunakan metode tanya jawab. Sejalan dengan pendapat (Ruminiati, 2008:242) "metode tanya jawab merupakan suatu metode yang bertujuan untuk menarik perhatian siswa agar lebih terpusat kepada pembelajaran". Dengan adaya metode ini pemahaman siswa menjadi lebih mendalam dan fokus dalam mengikuti proses pembelajaran. Apabila saat proses pembelajaran siswa kurang serius, kurang konsentrasi, guru dapat melontarkan pertanyaan kepada siswa sebagai salah satu upaya membangkitkan konsentrasi siswa dengan demikian siswa menjadi lebih konsentrasi dalam proses pebelajaran. Sejalan dengan pendapat (Shoimin, 2014) menyatakan bahwa, sebagai seorang guru yang setiap hari berinteraksi dengan muridnya dapat melakukan inovasi dalam pembelajaran. Guru yang memiliki kemauan dalam menggali metode dalam pembelajaran akan menciptakan model-model baru sehingga murid tidak mengalami kebosanan serta dapat menggali pengetahuan dan pengalaman secara maksimal.

Jadi, dalam proses pembelajaran yang sudah dilaksanakan guru sudah baik, namun berdasarkan pedoman observasi ada beberapa indikator yang belum dipenuhi guru secara maksimal yaitu penggunaan media dalam proses pembelajaran, menumbuhkan partisipasi dan kebiasaan positif siswa, menumbuhkan keceriaan dan antusiasme dalam proses belajar, melakukan penilaian akhir sesuai dengan kompetensi untuk memantau kemajuan belajar siswa, karena indikator tersebut mempengaruhi kemampuan siswa dalam proses pembelajaran.

Berdasarkan hal tersebut perlu adanya inovasi dan kreasi pembelajaran untuk penguasaan terhadap materi khususnya pecahan sederhana dan ditampilan secara professional, dari hati dan tanpa paksaan, logis dan menyenangkan serta dipadukan dengan pendekatan personal-emosional terhadap peserta didik akan menjadikan proses pembelajaran yang ingin dicapai terwujud.

Berdasarkan hasil wawancara dengan beberapa siswa dan guru dapat disimpulkan bahwa faktor-faktor kesulitan siswa dalam menyelesaikan operasi hitung pecahan terbagi dalam dua faktor yaitu faktor internal dan eksternal. Untuk faktor internal terdiri dari tiga faktor yaitu faktor pengetahuan awal siswa, faktor pemahaman konsep siswa dan faktor minat dan motivasi siswa. Untuk faktor eksternal juga terdiri dari tiga faktor, yaitu faktor guru, faktor sarana prasarana, faktor lingkungan, dan kegiatan belajar mengajar.

\section{Simpulan dan Saran}

Berdasarkan hasil penelitian dapat disimpulkan bahwa: (1) rata-rata hasil tes secara klasikal 64,07 dengan kategori rendah. (2) Kesulitan yang dihadapi siswa dalam menyelesaikan soal pecahan sederhana yaitu membandingkan pecahan sederhana, memahami soal cerita. Solusi untuk mengatasi hal tersebut adalah sering memberikan latihan soal, menggunakan bahasa Indonesia dalam pembelajaran, memberikan banyak variasi soal dan perlu adanya inovasi dalam proses pembelajaran. (3) Faktor penyebab kesulitan dalam menyelesaikan soal pecahan sederhana berdasarkan hasil wawancara dengan guru wali kelas III secara umum meliputi minat dan motivasi, faktor guru, faktor lingkunganfaktor guru, faktor sarana prasarana, faktor lingkungan, dan kegiatan belajar mengajar 
Saran yang dapat disampiakan berdasarkan penelitian yang telah dilakukan adalah sebagai berikut: 1) Siswa dalam mengikuti proses pembelajaran diharapkan selalu terlibat secara aktif agar mendapatkan pengetahuan baru melalui pengalaman yang ditemukan sendiri, 2) Guru dalam melaksanakan proses pembelajaran hendaknya lebih berinovasi dalam memilih alat peraga, media, metode maupun model pembelajaran yang mampu mengatasi kebutuhan belajar dan karakteristik siswa, karena aspek tersebut sangatlah penting dan mempengaruhi berhasil tidaknya suatu pembelajaran, 3) Kepala sekolah, khusunya SD hendaknya dapat menjadikan analisis kemampuan siswa dalam menyelesaikan soal pecahan yang harus diterapkan untuk mengetahui sejauhmana kemampuan siswa agar dapat diperbaiki kembali sehingga lebih meningkatkan kemampuan siswa, dan 4) Peneliti lain yang akan mengadakan penelitian lebih lanjut tentang analisis kemampuan menyelesaikan soal pecahan sederhana maupun pelajaran lain yang sesuai agar lebih memperhatikan kesulitan-kesulitan yang dialami dalam peneliti ini sebagai bahan pertimbangan untuk perbaikan dan penyempurnaan penelitian yang akan dilaksanakan..

\section{Daftar Pustaka}

Agung, A. A. Gede. 2014. Buku Ajar Metodologi Penelitian Pendidikan. Yogyakarta: Aditya Media Publishing.

Andika, I Gede Agus Ari. 2017." Pengaruh Pendekatan Kontekstual Berbantuan Media Konkret Terhadap Hasil Belajar Matematika Dengan Kovariabel Kemampuan Numerik Pada Siswa Kelas IV". E-Journal PGSD Universitas Pendidikan Ganesha, Volume: 5 Nomor: 2.

Budiasih, Luh. 2017 "Pengaruh Pendekatan Matematika Realistik Berbasis Pemecahan Masalah Terhadap Hasil Belajar Matematika Siswa Kelas V SD". E-Journal PGSD Universitas Pendidikan Ganesha, Volume: 5 Nomor: 2.

Dantes, Nyoman. 2012.Metodologi Penelitian. Yogyakarta: Andi Yogyakarta.

Depdiknas, 2003. Undang-undang No. 20 Tahun tentang sistem Pendidikan Nasional, Jakarta: Depdiknas.

Japa, I Gusti Ngurah dan I Made Suarjana. 2015. Pendidikan Matematika I. Singaraja: Universitas Pendidikan Ganesha.

Lestari, Karunia Eka dan Yudhanegara, Ridwan. 2017. Penelitian Pendidikan Matematika. Bandung: Refika Aditama.

Rudhiyama, Gd. 2016. "Pengaruh Pendekatan Starter Eksperimen Untuk Meningkatkan Hasil Belajar Matematika Siswa Kelas V SD”. E-Journal PGSD Universitas Pendidikan Ganesha, Volume 4, Nomor 1.

Sanjaya, H. Wina, 2013. Penelitian Pendidikan. Jakarta: Prenadamedia Group.

Septiani, Nyoman Dewi. 2016. "Penerapan Pemberian Sugesti Positif dengan Model Savi untuk Meningkatkan Hasil Belajar Matematika Siswa Kelas V" E-Journal PGSD Universitas Pendidikan Ganesha, Volume 4, Nomor 1.

Shoimin, A.2014. 68 Model Pembelajaran Terpadu. Yogyakarta: Ar-Ruzzmedia.

Suaryani, Ni Wyn. 2016. "Analisis Kemampuan Siswa Dalam Menyelesaikan Operasi Hitung Pecahan Pada Siswa Kelas V". E-Journal PGSD Universitas Pendidikan Ganesha, Volume 4, Nomor 1.

Susanto, Ahmad. 2013. Teori Belajar dan Pembelajaran di SD.Jakarta:Prenadamedia Group 